\title{
The Therapeutic Targeting of HGF/c-Met Signaling in Hepatocellular Carcinoma: Alternative Approaches
}

\author{
Chi-Tan $\mathrm{Hu}^{1}{ }^{1}$, Jia-Ru Wu ${ }^{2}$, Chuan-Chu Cheng ${ }^{2}$ and Wen-Sheng $\mathrm{Wu}^{2, *}$ \\ 1 Research Centre for Hepatology, Department of Internal Medicine, Buddhist Tzu Chi General Hospital and \\ Tzu Chi University, Hualien 970, Taiwan; chitan.hu@msa.hinet.net \\ 2 Department of Laboratory Medicine and Biotechnology, College of Medicine, Tzu Chi University, \\ Hualien 970, Taiwan; u8931246@yahoo.com.tw (J.-R.W.); cordiallove@yahoo.com.tw (C.-C.C.) \\ * Correspondence: wuwstcu1234@yahoo.com.tw
}

Academic Editor: Jill M. Siegfried

Received: 3 March 2017; Accepted: 24 May 2017; Published: 26 May 2017

\begin{abstract}
The poor prognosis of hepatocellular carcinoma (HCC), one of the most devastating cancers worldwide, is due to frequent recurrence and metastasis. Among the metastatic factors in the tumor microenvironment, hepatocyte growth factor (HGF) has been well known to play critical roles in tumor progression, including HCC. Therefore, c-Met is now regarded as the most promising therapeutic target for the treatment of HCC. However, there are still concerns about resistance and the side effects of using conventional inhibitors of c-Met, such as tyrosine kinase inhibitors. Recently, many alternative strategies of c-Met targeting have been emerging. These include targeting the downstream effectors of c-Met, such as hydrogen peroxide-inducible clone 5 (Hic-5), to block the reactive oxygen species (ROS)-mediated signaling for HCC progression. Also, inhibition of endosomal regulators, such as $\mathrm{PKC} \varepsilon$ and GGA3, may perturb the c-Met endosomal signaling for HCC cell migration. On the other hand, many herbal antagonists of c-Met-dependent signaling, such as saponin, resveratrol, and LZ-8, were identified. Taken together, it can be anticipated that more effective and safer c-Met targeting strategies for preventing HCC progression can be established in the future.
\end{abstract}

Keywords: hepatocellular carcinoma; metastasis; hepatocyte growth factor; c-Met; signaling transduction; therapeutic target

\section{Introduction}

The poor prognosis of hepatocellular carcinoma (HCC), one of the most devastating cancers worldwide, is due to frequent recurrence and metastasis after surgical resection. In the tumor microenvironment, growth factors and cytokines, such as hepatocyte growth factor (HGF) [1-5] and epidermal growth factor (EGF) [6-8], are frequently secreted from tumor cells and/or tumor-associated stromal and inflammatory cells. Most of them are capable of triggering metastatic changes, including epithelial mesenchymal transition (EMT), enhancement of motility, and invasiveness of varieties of tumor cells [9-11], and thus may be collectively called "metastatic growth factors". Among the metastatic factors, HGF has been well known to play critical roles in HCC progression. In previous clinical studies, the serum HGF level correlated positively with the tumor metastasis of HCC. Moreover, expression of c-Met, the receptor tyrosine kinase (RTK) of HGF, was closely associated with early recurrence [12]. The HGF in the HCC environment may be derived not only from tumor cells (autocrine) but also from cancer-associated cells (paracrine). Cancer cells may secrete molecules to trigger HGF expression in stromal fibroblasts, which in turn stimulate the progression of cancer cells (for review [3]). Specifically, one recent study demonstrated that HGF can be secreted from cancer-associated fibroblasts for the initiation of HCC in the context of cirrhosis $[13,14]$. On the other 
hand, in vitro studies also demonstrated the effects of HGF on phenotypical changes of HCC, including EMT, migration, and invasion [15-18]. Moreover, the c-Met receptor has been known to be a key player in drug resistance [19]. It has been established that cancer stem cells, which are capable of self-renewal and differentiation, are responsible for tumor progression and chemoresistance. Interestingly, HGF may regulate the development of cancer stem cells in HCC via c-Met/FRA1/HEY1 cascade [13,20]. Therefore, c-Met is now regarded as one of the most promising therapeutic targets for the treatment of HCC [21-27]. It is worth exploring the detailed mechanisms of HGF/c-Met signaling in order to identify more suitable targets to devise more effective and safer therapeutic strategies.

\section{HGF-c-Met Signaling Mediates Tumor Progression}

The receptor of HGF, c-Met, is a RTK consisting of a disulphide-linked heterodimeric complex with an extracellular portion for ligand binding, a membrane spanning segment, a juxtamembrane domain, a catalytic domain, and a C-terminal docking site [28]. Binding of the HGF to c-Met triggers dimerization and autophosphorylation of its cytoplasmic domain. Many adaptor proteins, such as Shc [29], Src, Grb2, and the p85 regulatory subunit of PI3K [28], may bind directly or indirectly to c-Met. Most of them contain a Src homologous2 (SH2) domain interacting with c-Met and a Src homologous3 (SH3) domain that binds to downstream signal molecules. Several downstream signaling pathways can be triggered by HGF/c-Met [1], including mitogen activated protein kinase MAPK) family such as ERK [30,31], p-38 [31,32], and Akt/PKB [30] pathways, which are shared by many other RTKs. HGF/c-Met can also cross talk with integrin-initiated signal cascades, leading to the activation of FAK-Src-paxillin, Ras-Rac1/Cdc42-PAK, and Gab1-Crk-C3G-Rap1 cascades [33]. Normally, the HGF-c-Met axis is critical for liver development, protection, and regeneration. However, uncontrolled HGF/c-MET signaling is one of the drivers of HCC progression [25]. HGF/c-MET signaling can be activated by metastasis associated with colon cancer 1 (MACC1) to inhibit HCC apoptosis facilitating HCC progression [34]. On the other hand, HGF-c-Met can be regulated by microRNAs, miR-26a, miR-198 [35,36], and a tumor suppressor called suppressor of cytokine signaling 1 (SOCS1) for inhibiting HCC progression [37]. Moreover, many studies demonstrated that autocrine activation of HGF/c-Met signaling was responsible for acquisition of sorafenib resistance in management of HCC [38,39].

\section{Target Therapy Aiming at c-Met against HCC Progression}

The therapeutic strategy aiming at HGF-c-Met signaling for the prevention of tumor progression of HCC was intensively investigated decades ago. Previously, many preclinical studies had strengthened the feasibility of targeting HGF-c-Met (for reviews [25,40]) for the treatment of HCC. For example, depletion of c-Met by siRNA decreased the progression of multiple HCC cell lines both in vitro and in vivo [38,41,42]. Also, PHA665752, a highly specific inhibitor of c-Met, significantly decreased the growth of subcutaneous xenografts of c-MET-overexpressing HCC cells in nude mice [43]. Currently, many clinical trials are being conducted for c-Met targeting in HCC management, using c-Met inhibitors such as INC280, foretinib, MSC2156119J, golvatinib, tivantinib, cabozantinib (for review [44]), tepotinib, and regorafenib (for review [45]). Among these, tivantinib and cabozantinib are entering phase III randomized controlled trials [44]. Also, recent clinical trials have revealed the efficacy of onartuzumab [46] and ficlatuzumab [47], antibodies against c-Met and HGF, respectively, in preventing tumor progression of solid tumors, including HCC. In addition, the potential use of c-Met-targeting miRNAs for suppressing aberrant c-Met signaling in HCC treatment is emerging [48]. In spite of this, there are still concerns about the feasibility of utilizing c-Met targeting approaches. In particular, resistance [49-52] and the side effects [53] of taking RTK inhibitors are issues that remain to be resolved.

\section{Resistance in c-Met Targeting}

There are many reports demonstrating the mechanisms for resistance to c-Met targeting, including the cross talk of c-Met with epidermal growth factor receptor EGFR [42], gene amplification of c-Met 
coupled with enhancement of K-RAS oncogene [39], and mutation in the activation loop of c-Met that destabilized its autoinhibitory conformation [43]. In addition, c-Met signaling may be activated in a HGF-independent fashion, such as by Des- $\gamma$-carboxy-prothrombin (DCP) [54] or cell attachment independent of the ligand [55]. Under these circumstances, inhibitors blocking the interaction of HGF and c-Met may be useless. Moreover, c-Met inhibition may trigger compensatory RTK signaling, such as EGFR/ErbB3 in HCC [56]. An additional cause of resistance is the unfeasibility of HCC patients enrolled in the trials. Previous studies indicated that c-Met overexpression was observed only in $20-48 \%$ of human HCC samples. For those HCC with negative c-Met signaling, the c-Met targeting approach will not be adequate.

\section{Side Effects in c-Met Targeting}

The toxicity of c-Met inhibitors has been demonstrated in recent studies. In animal experiments, the highly selective c-Met inhibitor GEN-203 and compound 8 may cause liver and bone marrow toxicity in mice [57] and myocardial degeneration in rats [58], respectively. In the clinical trials, severe adverse events, including leukopenia, anemia, and neutropenia, were observed in a phase $1 \mathrm{~b}$ study of tivantinib (ARQ197) for patients with HCC [59]. In addition, foretinib caused fatigue, hypertension, and gastrointestinal toxicities for patients with papillary renal cell carcinoma [60].

The aforementioned side effects caused by c-Met inhibition may be associated with the biological functions of c-Met. HGF and c-Met are broadly expressed in epithelial cells of many organs, playing essential physiological roles [61]. Importantly, HGF/c-Met is responsible for the defensive physiological response to tissue damage and has cytoprotective activity in vivo [61]. Therefore, c-Met targeting therapy may result in the blocking of such important physiological functions, rendering the patient more susceptible to tissue damage. In addition, since many physiologically important RTKs share similar structures and functions with c-Met, they may also be affected by c-Met antagonist as off-targets.

\section{Targeting Downstream Effector of c-Met Improves c-Met Target Therapy}

There are strategies that may address the aforementioned issues in c-Met target therapy. One of them is the targeting of downstream effectors of c-Met specifically involved in tumor progression. Previously, polypeptides competing with downstream effectors of c-Met were developed. For example, antagonists of the Grb2 SH2 domain were used to prevent metastasis mediated by c-Met [62]. Moreover, indirect blocking of c-Met signaling was achieved by using specific inhibitors of downstream effectors of c-Met, such as Src, PtdIns3K/AKT, MAPK, or STAT3 [61]. However, most of the aforementioned signaling pathways are also downstream of other essential RTKs, raising the problems of unwanted targeting and unpredicted side effects. Therefore, targeting of more specific downstream effectors of c-Met for tumor progression is needed.

\subsection{Hic-5 as a Specific Downstream Target of c-Met Pathway}

One of the c-Met downstream effectors that is more feasible as a therapeutic target may be the hydrogen peroxide-inducible clone- 5 (Hic-5), which was first identified in a screen for TGF $\beta 1$ and hydrogen peroxide-inducible genes [63]. Hic-5 belongs to the paxillin superfamily, the well-known focal adhesion adaptor molecules [64]. Within the paxillin superfamily, Hic-5 is the most homologous to paxillin, and both of them may play distinct, but complementary roles in triggering cancer progression [65]. In our recent report, we found that Hic-5 can be induced by HGF [66]. Moreover, Hic-5 regulated the reactive oxygen species (ROS)-JNK-signaling pathway for HCC progression induced by HGF [66]. Accordingly, we proposed that Hic-5 plays an important role in mediating c-Met signaling and tumor metastasis of HCC. One more intriguing characteristic of Hic-5 is that its tissue distribution is rather limited (normally expressed in the lung, spleen, and smooth muscle layer of tissues) as compared with paxillin (which is ubiquitously expressed), thus it may serve as a more specific and safer target for HCC therapy. 


\subsection{Targeting c-Met Endosomal Signaling of c-Met}

Recently, the role of endosomal signaling in tumor progression triggered by metastatic growth factors, including HGF, has been highlighted [67]. Receptor endocytosis, either clathrin (CLA)-dependent or -independent, has a profound impact on signal transduction $[68,69]$. After ligand-induced RTK endocytosis, signal transduction can be sustained within the early endosome, which may recycle back to the plasma membrane or be subjected to ubiquitin-directed lysosomal degradation $[68,69]$. Importantly, endosomal sorting may regulate signaling pathways in a temporal and spatial manner, which is required for cell migration [70]. Moreover, HGF may recruit Golgi-localized, gamma ear-containing, Arf-binding proteins 3 (GGA3) to promote c-Met recycling and sustain ERK activation [71,72]. Several lines of evidences supported that PKC may regulate endosomal processing of RTK $[68,73]$, including c-Met $[74,75]$. In our recent study, we demonstrated that HGF-induced c-Met endocytosis directs fluctuant JNK and paxillin signaling in a PKC $\varepsilon$ - and GGA3-dependent manner, leading to HCC cell migration [76]. This was achieved by c-Met degradation and recycling mediated by PKC $\varepsilon$ and GGA3, respectively [76].

Previously, c-Met endocytosis had been found to be critical in breast cancer tumorigenesis, which can be prevented by two endocytosis blockers, ConA and dynasore [77]. Recently, Kermorgant et al. suggested that the critical components within c-Met endocytic trafficking could be categorized as novel targets for the prevention of tumor progression [78]. Therefore, critical endosomal signaling components of c-Met such as PKC $\varepsilon$ - and GGA3, may be potential specific targets within c-Met signaling for preventing HCC progression.

\section{Using Herbal Medicinal Antagonists of c-Met to Achieve More Effective and Safer c-Met Targeting}

Another strategy for avoiding the problems of HGF-c-Met target therapy is the use of natural herbal drugs instead of synthetic chemical agents. For example, Timosaponin AIII (TAIII), a steroidal saponin, may suppress HGF-induced invasive activity [79]. Moreover, resveratrol, one of the major polyphenols found in red wine, prevents HCC progression by down-regulation of the HGF-c-Met signaling pathway [80]. The mechanisms for the anti-tumor effect of the herbal drugs may be rather different from those of the conventional kinase-based synthetic inhibitors. For example, Ephedrae herba, an ingredient of Maoto, which is a traditional Kampo medicine capable of preventing progression of breast cancer and mouse osteosarcoma, can downregulate the c-Met signal by promoting HGF-stimulated c-Met endocytosis and its degradation [81]. Moreover, our recent studies have demonstrated that LZ-8 (also known as Ling-Zhi or Reishi, purified from a Ganoderma lucidium) blocked both c-Met-dependent and -independent MAPK signaling for anti-HCC progression [82].

\section{Conclusions}

Target therapy aimed at the HGF/c-Met pathway is promising for the suppression of HCC progression. However, the problems of resistance and side effects in conventional kinase-based c-Met targeting remain unresolved. Many alternative strategies are emerging which aim to be more effective and safer. These include targeting the downstream effector of c-Met and using herbal drugs as safer antagonists of c-Met (summarized in Figure 1). 


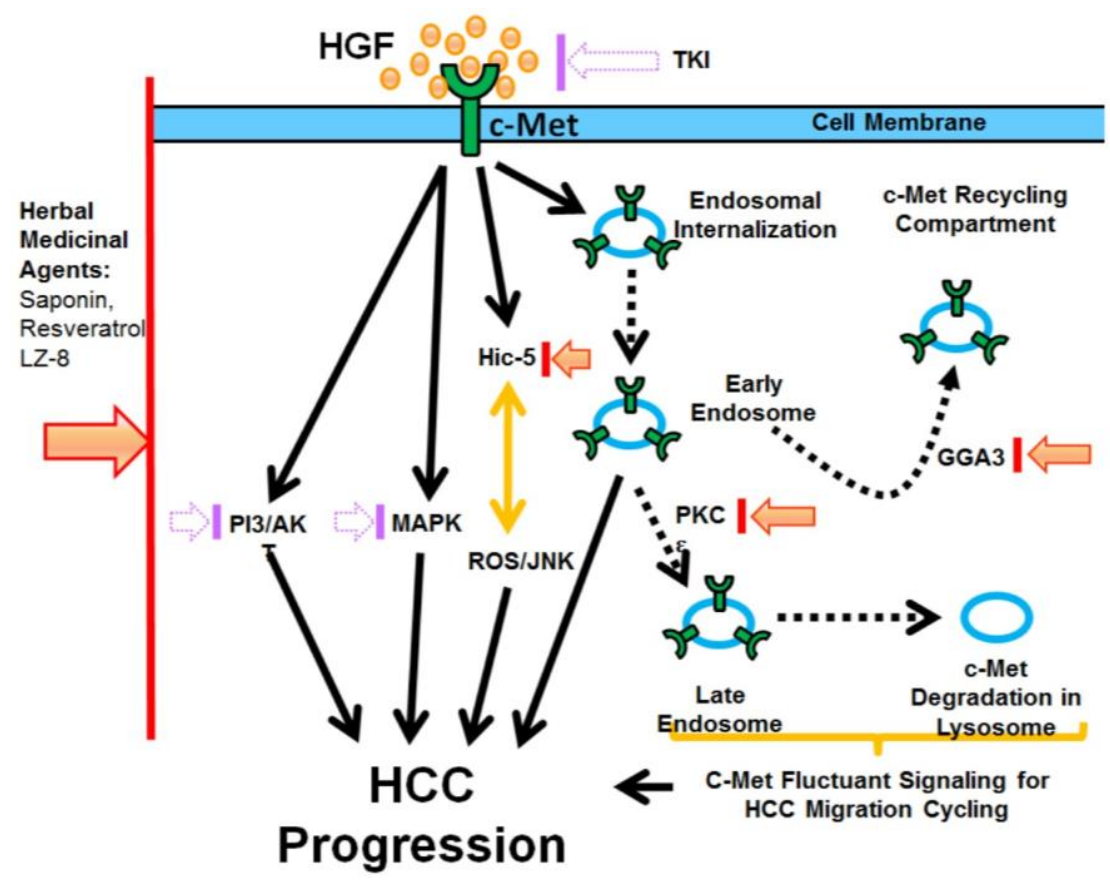

Figure 1. Strategies of effective targeting of hepatocyte growth factor (HGF)/c-Met signaling for the prevention of hepatocellular carcinoma (HCC). Ligand binding of c-Met triggers multiple signaling pathways, including the conventional PI3K/AKT and MAPK, coupled with the Hic-5-reactive oxygen species (ROS)-c-jun-N-terminal kinase (JNK) cascade. It also induces the c-Met endosomal pathway, including early endosomal and late endosomal, and recycling of the c-Met pathway for c-Met-mediated fluctuant signaling for HCC migration. Altogether, these pathways lead to HCC progression. Conventional blocking of c-Met signaling by a tyrosine kinase inhibitor (TKI) of c-Met or by agonists of $\mathrm{PI} 3 \mathrm{~K} / \mathrm{AKT}$ and MAPK may cause resistance or side effects (shown as dotted arrows in purple), whereas blocking of the Hic-5-ROS-JNK cascade is proposed to be more promising (shown as solid arrows in orange-red). In addition, the inhibition of the endosomal regulators PKC $\varepsilon$ and GGA3 (shown as solid arrows in orange-red) may perturb the c-Met fluctuant signaling for cell migration. On the other hand, using herbal drugs against c-Met-dependent signaling (shown as solid arrows in orange-red) is proposed to be more effective and safer.

Conflicts of Interest: The authors declare no conflict of interest.

\section{References}

1. Trusolino, L.; Bertotti, A.; Comoglio, P.M. Met signalling: Principles and functions in development, organ regeneration and cancer. Nat. Rev. Mol. Cell Biol. 2010, 11, 834-848. [CrossRef] [PubMed]

2. Zhou, H.Y.; Pon, Y.L.; Wong, A.S. Hgf/met signaling in ovarian cancer. Curr. Mol. Med. 2008, 8, 469-480. [CrossRef] [PubMed]

3. Matsumoto, K.; Nakamura, T.; Sakai, K.; Nakamura, T. Hepatocyte growth factor and met in tumor biology and therapeutic approach with nk4. Proteomics 2008, 8, 3360-3370. [CrossRef] [PubMed]

4. Benvenuti, S.; Comoglio, P.M. The met receptor tyrosine kinase in invasion and metastasis. J. Cell. Physiol. 2007, 213, 316-325. [CrossRef] [PubMed]

5. Lesko, E.; Majka, M. The biological role of hgf-met axis in tumor growth and development of metastasis. Front. Biosci. 2008, 13, 1271-1280. [CrossRef] [PubMed]

6. Quesnelle, K.M.; Boehm, A.L.; Grandis, J.R. Stat-mediated egfr signaling in cancer. J. Cell. Biochem. 2007, 102, 311-319. [CrossRef] [PubMed]

7. Normanno, N.; De Luca, A.; Bianco, C.; Strizzi, L.; Mancino, M.; Maiello, M.R.; Carotenuto, A.; De Feo, G.; Caponigro, F.; Salomon, D.S. Epidermal growth factor receptor (egfr) signaling in cancer. Gene 2006, 366, 2-16. [CrossRef] [PubMed] 
8. De Luca, A.; Carotenuto, A.; Rachiglio, A.; Gallo, M.; Maiello, M.R.; Aldinucci, D.; Pinto, A.; Normanno, N. The role of the egfr signaling in tumor microenvironment. J. Cell. Physiol. 2008, 214, 559-567. [CrossRef] [PubMed]

9. Osada, S.; Kanematsu, M.; Imai, H.; Goshima, S. Clinical significance of serum hgf and c-met expression in tumor tissue for evaluation of properties and treatment of hepatocellular carcinoma. Hepato-Gastroenterology 2008, 55, 544-549. [PubMed]

10. Ogunwobi, O.O.; Liu, C. Hepatocyte growth factor upregulation promotes carcinogenesis and epithelial-mesenchymal transition in hepatocellular carcinoma via akt and cox-2 pathways. Clin. Exp. Metastasis 2008, 28, 721-731. [CrossRef] [PubMed]

11. Jiang, Y.; Xu, W.; Lu, J.; He, F.; Yang, X. Invasiveness of hepatocellular carcinoma cell lines: Contribution of hepatocyte growth factor, c-met, and transcription factor ets-1. Biochem. Biophys. Res. Commun. 2001, 286, 1123-1130. [CrossRef] [PubMed]

12. Ogunwobi, O.O.; Wang, T.; Zhang, L.; Liu, C. Cyclooxygenase-2 and akt mediate multiple growth-factor-induced epithelial-mesenchymal transition in human hepatocellular carcinoma. J. Gastroenterol. Hepatol. 2008, 27, 566-578. [CrossRef] [PubMed]

13. Lau, E.Y.; Lo, J.; Cheng, B.Y.; Ma, M.K.; Lee, J.M.; Ng, J.K.; Chai, S.; Lin, C.H.; Tsang, S.Y.; Ma, S.; et al. Cancer-Associated Fibroblasts Regulate Tumor-Initiating Cell Plasticity in Hepatocellular Carcinoma through c-Met/FRA1/HEY1 Signaling. Cell Rep. 2016, 15, 1175-1189. [CrossRef] [PubMed]

14. Jia, C.C.; Wang, T.T.; Liu, W.; Fu, B.S.; Hua, X.; Wang, G.Y.; Li, T.J.; Li, X.; Wu, X.Y.; Tai, Y.; et al. Cancer-associated fibroblasts from hepatocellular carcinoma promote malignant cell proliferation by HGF secretion. PLoS ONE 2013, 8, e63243. [CrossRef] [PubMed]

15. Poste, G.; Fidler, I.J. The pathogenesis of cancer metastasis. Nature 1980, 283, 139-146. [CrossRef] [PubMed]

16. Roussos, E.T.; Condeelis, J.S.; Patsialou, A. Chemotaxis in cancer. Nat. Rev. Cancer 2011, 11, $573-587$. [CrossRef] [PubMed]

17. Condeelis, J.; Segall, J.E. Intravital imaging of cell movement in tumours. Nat. Rev. Cancer 2003, 3, 921-930. [CrossRef] [PubMed]

18. Whittaker, S.; Marais, R.; Zhu, A.X. The role of signaling pathways in the development and treatment of hepatocellular carcinoma. Oncogene 2010, 29, 4989-5005. [CrossRef] [PubMed]

19. Maroun, C.R.; Rowlands, T. The met receptor tyrosine kinase: A key player in oncogenesis and drug resistance. Pharmacol. Ther. 2014, 142, 316-338. [CrossRef] [PubMed]

20. Diaz-Coranguez, M.; Segovia, J.; Lopez-Ornelas, A.; Puerta-Guardo, H.; Ludert, J.; Chavez, B.; Meraz-Cruz, N.; Gonzalez-Mariscal, L. Transmigration of neural stem cells across the blood brain barrier induced by glioma cells. PLoS ONE 2013, 8, e60655. [CrossRef] [PubMed]

21. You, H.; Ding, W.; Dang, H.; Jiang, Y.; Rountree, C.B. c-Met represents a potential therapeutic target for personalized treatment in hepatocellular carcinoma. Hepatology 2011, 54, 879-889. [CrossRef] [PubMed]

22. Gao, J.; Inagaki, Y.; Song, P.; Qu, X.; Kokudo, N.; Tang, W. Targeting c-met as a promising strategy for the treatment of hepatocellular carcinoma. Pharmacol. Res. 2012, 65, 23-30. [CrossRef] [PubMed]

23. Blagotinsek, K.; Rozman, D. Targeting signalling pathways in hepatocellular carcinoma. Curr. Pharm. Des. 2016, 23, 170-175. [CrossRef] [PubMed]

24. Giordano, S.; Columbano, A. Met as a therapeutic target in hcc: Facts and hopes. J. Hepatol. 2014, 60, 442-452. [CrossRef] [PubMed]

25. Goyal, L.; Muzumdar, M.D.; Zhu, A.X. Targeting the hgf/c-met pathway in hepatocellular carcinoma. Clin. Cancer Res. 2013, 19, 2310-2318. [CrossRef] [PubMed]

26. Graveel, C.R.; Tolbert, D.; Vande Woude, G.F. Met: A critical player in tumorigenesis and therapeutic target. Cold Spring Harb. Perspect. Biol. 2013, 5, a009209. [CrossRef] [PubMed]

27. Gao, F.; Deng, G.; Liu, W.; Zhou, K.; Li, M. Resveratrol suppresses human hepatocellular carcinoma via targeting HGF-c-Met signaling pathway. Oncol Rep. 2017, 37, 1203-1211. [CrossRef] [PubMed]

28. Ponzetto, C.; Bardelli, A.; Zhen, Z.; Maina, F.; dalla Zonca, P.; Giordano, S.; Graziani, A.; Panayotou, G.; Comoglio, P.M. A multifunctional docking site mediates signaling and transformation by the hepatocyte growth factor/scatter factor receptor family. Cell 1994, 77, 261-271. [CrossRef]

29. Pelicci, G.; Giordano, S.; Zhen, Z.; Salcini, A.E.; Lanfrancone, L.; Bardelli, A.; Panayotou, G.; Waterfield, M.D.; Ponzetto, C.; Pelicci, P.G.; et al. The motogenic and mitogenic responses to hgf are amplified by the shc adaptor protein. Oncogene 1995, 10, 1631-1638. [PubMed] 
30. Zeng, Q.; Chen, S.; You, Z.; Yang, F.; Carey, T.E.; Saims, D.; Wang, C.Y. Hepatocyte growth factor inhibits anoikis in head and neck squamous cell carcinoma cells by activation of erk and akt signaling independent of nfkappa b. J. Biol. Chem. 2002, 277, 25203-25208. [CrossRef] [PubMed]

31. Lee, K.H.; Hyun, M.S.; Kim, J.R. Growth factor-dependent activation of the mapk pathway in human pancreatic cancer: Mek/erk and p38 map kinase interaction in upa synthesis. Clin. Exp. Metastasis 2003, 20, 499-505. [CrossRef] [PubMed]

32. Recio, J.A.; Merlino, G. Hepatocyte growth factor/scatter factor activates proliferation in melanoma cells through p38 mapk, atf-2 and cyclin d1. Oncogene 2002, 21, 1000-1008. [CrossRef] [PubMed]

33. Kermorgant, S.; Parker, P.J. C-met signalling: Spatio-temporal decisions. Cell Cycle 2005, 4, 352-355. [CrossRef] [PubMed]

34. Yao, Y.; Dou, C.; Lu, Z.; Zheng, X.; Liu, Q. Macc1 suppresses cell apoptosis in hepatocellular carcinoma by targeting the hgf/c-met/akt pathway. Cell Physiol. Biochem. 2015, 35, 983-996. [CrossRef] [PubMed]

35. Yang, X.; Zhang, X.F.; Lu, X.; Jia, H.L.; Liang, L.; Dong, Q.Z.; Ye, Q.H.; Qin, L.X. Microrna-26a suppresses angiogenesis in human hepatocellular carcinoma by targeting hepatocyte growth factor-cmet pathway. Hepatology 2014, 59, 1874-1885. [CrossRef] [PubMed]

36. Tan, S.; Li, R.; Ding, K.; Lobie, P.E.; Zhu, T. Mir-198 inhibits migration and invasion of hepatocellular carcinoma cells by targeting the hgf/c-met pathway. FEBS Lett. 2011, 585, 2229-2234. [CrossRef] [PubMed]

37. Gui, Y.; Yeganeh, M.; Donates, Y.C.; Tobelaim, W.S.; Chababi, W.; Mayhue, M.; Yoshimura, A.; Ramanathan, S.; Saucier, C.; Ilangumaran, S. Regulation of met receptor tyrosine kinase signaling by suppressor of cytokine signaling 1 in hepatocellular carcinoma. Oncogene 2015, 34, 5718-5728. [CrossRef] [PubMed]

38. Han, P.; Li, H.; Jiang, X.; Zhai, B.; Tan, G.; Zhao, D.; Qiao, H.; Liu, B.; Jiang, H.; Sun, X. Dual inhibition of akt and c-met as a second-line therapy following acquired resistance to sorafenib in hepatocellular carcinoma cells. Mol. Oncol. 2017, 11, 320-334. [CrossRef] [PubMed]

39. Firtina Karagonlar, Z.; Koc, D.; Iscan, E.; Erdal, E.; Atabey, N. Elevated hepatocyte growth factor expression as an autocrine c-met activation mechanism in acquired resistance to sorafenib in hepatocellular carcinoma cells. Cancer Sci. 2016, 107, 407-416. [CrossRef] [PubMed]

40. Gao, J.J.; Inagaki, Y.; Xue, X.; Qu, X.J.; Tang, W. c-Met: A potential therapeutic target for hepatocellular carcinoma. Drug Discov. Ther. 2011, 5, 2-11. [CrossRef] [PubMed]

41. Heideman, D.A.; Overmeer, R.M.; van Beusechem, V.W.; Lamers, W.H.; Hakvoort, T.B.; Snijders, P.J.; Craanen, M.E.; Offerhaus, G.J.; Meijer, C.J.; Gerritsen, W.R. Inhibition of angiogenesis and hgf-cmet-elicited malignant processes in human hepatocellular carcinoma cells using adenoviral vector-mediated nk4 gene therapy. Cancer Gene Ther. 2005, 12, 954-962. [CrossRef] [PubMed]

42. Xie, B.; Xing, R.; Chen, P.; Gou, Y.; Li, S.; Xiao, J.; Dong, J. Down-regulation of c-met expression inhibits human hcc cells growth and invasion by rna interference. J. Surg. Res. 2010, 162, 231-238. [CrossRef] [PubMed]

43. Okuma, H.S.; Kondo, S. Trends in the development of met inhibitors for hepatocellular carcinoma. Future Oncol. 2016, 12, 1275-1286. [CrossRef] [PubMed]

44. Qi, X.S.; Guo, X.Z.; Han, G.H.; Li, H.Y.; Chen, J. MET inhibitors for treatment of advanced hepatocellular carcinoma: A review. World J. Gastroenterol. 2015, 21, 5445-5453. [CrossRef] [PubMed]

45. Woo, H.Y.; Yoo, S.Y.; Heo, J. New chemical treatment options in second-line hepatocellular carcinoma: What to do when sorafenib fails? Expert Opin. Pharmacother. 2016, 18, 35-44. [CrossRef] [PubMed]

46. Nishio, M.; Horiike, A.; Nokihara, H.; Horinouchi, H.; Nakamichi, S.; Wakui, H.; Ohyanagi, F.; Kudo, K.; Yanagitani, N.; Takahashi, S.; et al. Phase I study of the anti-MET antibody onartuzumab in patients with solid tumors and MET-positive lung cancer. Investig. New Drugs 2015, 33, 632-640. [CrossRef] [PubMed]

47. Tabernero, J.; Elez, M.E.; Herranz, M.; Rico, I.; Prudkin, L.; Andreu, J.; Mateos, J.; Carreras, M.J.; Han, M.; Gifford, J.; et al. A pharmacodynamic/pharmacokinetic study of ficlatuzumab in patients with advanced solid tumors and liver metastases. Clin. Cancer Res. 2014, 20, 2793-2804. [CrossRef] [PubMed]

48. Karagonlar, Z.F.; Korhan, P.; Atabey, N. Targeting c-Met in Cancer by MicroRNAs: Potential Therapeutic Applications in Hepatocellular Carcinoma. Drug Dev. Res. 2015, 76, 357-367. [CrossRef] [PubMed]

49. Cepero, V.; Sierra, J.R.; Corso, S.; Ghiso, E.; Casorzo, L.; Perera, T.; Comoglio, P.M.; Giordano, S. Met and kras gene amplification mediates acquired resistance to met tyrosine kinase inhibitors. Cancer Res. 2010, 70, 7580-7590. [CrossRef] [PubMed] 
50. Blivet-Van Eggelpoel, M.J.; Chettouh, H.; Fartoux, L.; Aoudjehane, L.; Barbu, V.; Rey, C.; Priam, S.; Housset, C.; Rosmorduc, O.; Desbois-Mouthon, C. Epidermal growth factor receptor and her-3 restrict cell response to sorafenib in hepatocellular carcinoma cells. J. Hepatol. 2012, 57, 108-115. [CrossRef] [PubMed]

51. McDermott, U.; Pusapati, R.V.; Christensen, J.G.; Gray, N.S.; Settleman, J. Acquired resistance of non-small cell lung cancer cells to met kinase inhibition is mediated by a switch to epidermal growth factor receptor dependency. Cancer Res. 2010, 70, 1625-1634. [CrossRef] [PubMed]

52. Qi, J.; McTigue, M.A.; Rogers, A.; Lifshits, E.; Christensen, J.G.; Janne, P.A.; Engelman, J.A. Multiple mutations and bypass mechanisms can contribute to development of acquired resistance to met inhibitors. Cancer Res. 2011, 71, 1081-1091. [CrossRef] [PubMed]

53. Li, Y.; Huang, J.W.; Lu, L.G.; Shao, P.J.; Hu, B.S.; Huang, G.M.; Wei, Z.G.; Zhang, L. Clinical analysis of the treatment: Transcatheter arterial chemoembolization combined with sorafenib in advanced hepatocellular carcinoma. Zhonghua Yi Xue Za Zhi 2010, 90, 2187-2192. [PubMed]

54. Suzuki, M.; Shiraha, H.; Fujikawa, T.; Takaoka, N.; Ueda, N.; Nakanishi, Y.; Koike, K.; Takaki, A.; Shiratori, Y. Des-gamma-carboxy prothrombin is a potential autologous growth factor for hepatocellular carcinoma. J. Biol. Chem. 2005, 280, 6409-6415. [CrossRef] [PubMed]

55. Wang, R.; Ferrell, L.D.; Faouzi, S.; Maher, J.J.; Bishop, J.M. Activation of the met receptor by cell attachment induces and sustains hepatocellular carcinomas in transgenic mice. J. Cell Boil. 2001, 153, 1023-1034. [CrossRef]

56. Steinway, S.N.; Dang, H.; You, H.; Rountree, C.B.; Ding, W. The egfr/erbb3 pathway acts as a compensatory survival mechanism upon c-met inhibition in human c-met+ hepatocellular carcinoma. PLoS ONE 2015, 10, e0128159. [CrossRef] [PubMed]

57. Diaz, D.; Ford, K.A.; Hartley, D.P.; Harstad, E.B.; Cain, G.R.; Achilles-Poon, K.; Nguyen, T.; Peng, J.; Zheng, Z.; Merchant, M.; et al. Pharmacokinetic drivers of toxicity for basic molecules: Strategy to lower pka results in decreased tissue exposure and toxicity for a small molecule met inhibitor. Toxicol. Appl. Pharmacol. 2013, 266, 86-94. [CrossRef] [PubMed]

58. Cui, J.J.; Shen, H.; Tran-Dube, M.; Nambu, M.; McTigue, M.; Grodsky, N.; Ryan, K.; Yamazaki, S.; Aguirre, S.; Parker, M.; et al. Lessons from (s)-6-(1-(6-(1-methyl-1h-pyrazol-4-yl)-[1,2,4]triazolo[4,3-b] pyridazin-3-yl)ethyl)quinoline (pf-04254644), an inhibitor of receptor tyrosine kinase c-met with high protein kinase selectivity but broad phosphodiesterase family inhibition leading to myocardial degeneration in rats. J. Med. Chem. 2013, 56, 6651-6665. [PubMed]

59. Santoro, A.; Simonelli, M.; Rodriguez-Lope, C.; Zucali, P.; Camacho, L.H.; Granito, A.; Senzer, N.; Rimassa, L.; Abbadessa, G.; Schwartz, B.; et al. A phase-1b study of tivantinib (arq 197) in adult patients with hepatocellular carcinoma and cirrhosis. Br. J. Cancer 2013, 108, 21-24. [CrossRef] [PubMed]

60. Choueiri, T.K.; Vaishampayan, U.; Rosenberg, J.E.; Logan, T.F.; Harzstark, A.L.; Bukowski, R.M.; Rini, B.I.; Srinivas, S.; Stein, M.N.; Adams, L.M.; et al. Phase ii and biomarker study of the dual met/vegfr2 inhibitor foretinib in patients with papillary renal cell carcinoma. J. Clin. Oncol. 2013, 31, 181-186. [CrossRef] [PubMed]

61. Birchmeier, C.; Birchmeier, W.; Gherardi, E.; Vande Woude, G.F. Met, metastasis, motility and more. Nat. Rev. Mol. Cell Biol. 2003, 4, 915-925. [CrossRef] [PubMed]

62. Atabey, N.; Gao, Y.; Yao, Z.J.; Breckenridge, D.; Soon, L.; Soriano, J.V.; Burke, T.R., Jr.; Bottaro, D.P. Potent blockade of hepatocyte growth factor-stimulated cell motility, matrix invasion and branching morphogenesis by antagonists of grb2 src homology 2 domain interactions. J. Biol. Chem. 2001, 276, 14308-14314. [CrossRef] [PubMed]

63. Shibanuma, M.; Mashimo, J.; Kuroki, T.; Nose, K. Characterization of the tgf beta 1-inducible hic-5 gene that encodes a putative novel zinc finger protein and its possible involvement in cellular senescence. J. Biol. Chem. 1994, 269, 26767-26774. [PubMed]

64. Brown, M.C.; Turner, C.E. Paxillin: Adapting to change. Physiol. Rev. 2004, 84, 1315-1339. [CrossRef] [PubMed]

65. Deakin, N.O.; Turner, C.E. Distinct roles for paxillin and hic-5 in regulating breast cancer cell morphology, invasion, and metastasis. Mol. Biol. Cell 2011, 22, 327-341. [CrossRef] [PubMed]

66. Wu, J.R.; Hu, C.T.; You, R.I.; Pan, S.M.; Cheng, C.C.; Lee, M.C.; Wu, C.C.; Chang, Y.J.; Lin, S.C.; Chen, C.S.; et al. Hydrogen peroxide inducible clone- 5 mediates reactive oxygen species signaling for hepatocellular carcinoma progression. Oncotarget 2015, 6, 32526-32544. [PubMed] 
67. Hu, C.T.; Wu, J.R.; Wu, W.S. The role of endosomal signaling triggered by metastatic growth factors in tumor progression. Cell. Signal. 2013, 25, 1539-1545. [CrossRef] [PubMed]

68. Sorkin, A.; von Zastrow, M. Endocytosis and signalling: Intertwining molecular networks. Nat. Rev. Mol. Cell Biol. 2009, 10, 609-622. [CrossRef] [PubMed]

69. McMahon, H.T.; Boucrot, E. Molecular mechanism and physiological functions of clathrin-mediated endocytosis. Nat. Rev. Mol. Cell Biol. 2011, 12, 517-533. [CrossRef] [PubMed]

70. Polo, S.; Di Fiore, P.P. Endocytosis conducts the cell signaling orchestra. Cell 2006, 124, 897-900. [CrossRef] [PubMed]

71. Parachoniak, C.A.; Luo, Y.; Abella, J.V.; Keen, J.H.; Park, M. Gga3 functions as a switch to promote met receptor recycling, essential for sustained erk and cell migration. Dev. Cell 2011, 20, 751-763. [CrossRef] [PubMed]

72. Clague, M.J. Met receptor: A moving target. Sci. Signal. 2011, 4, pe40. [CrossRef] [PubMed]

73. Alvi, F.; Idkowiak-Baldys, J.; Baldys, A.; Raymond, J.R.; Hannun, Y.A. Regulation of membrane trafficking and endocytosis by protein kinase c: Emerging role of the pericentrion, a novel protein kinase c-dependent subset of recycling endosomes. Cell. Mol. Life Sci. 2007, 64, 263-270. [CrossRef] [PubMed]

74. Kermorgant, S.; Zicha, D.; Parker, P.J. Protein kinase c controls microtubule-based traffic but not proteasomal degradation of c-met. J. Biol. Chem. 2003, 278, 28921-28929. [CrossRef] [PubMed]

75. Kermorgant, S.; Zicha, D.; Parker, P.J. Pkc controls hgf-dependent c-met traffic, signalling and cell migration. EMBO J. 2004, 23, 3721-3734. [CrossRef] [PubMed]

76. Hu, C.T.; Cheng, C.C.; Wu, J.R.; Pan, S.M.; Wu, W.S. Pkcepsilon-mediated c-met endosomal processing directs fluctuant c-met-jnk-paxillin signaling for tumor progression of hepg2. Cell. Signal. 2015, 27, 1544-1555. [CrossRef] [PubMed]

77. Joffre, C.; Barrow, R.; Menard, L.; Calleja, V.; Hart, I.R.; Kermorgant, S. A direct role for met endocytosis in tumorigenesis. Nat. Cell Biol. 2011, 13, 827-837. [CrossRef] [PubMed]

78. Barrow-McGee, R.; Kermorgant, S. Met endosomal signalling: In the right place, at the right time. Int. J. Biochem. Cell Biol. 2014, 49, 69-74. [CrossRef] [PubMed]

79. Tsai, C.H.; Yang, C.W.; Wang, J.Y.; Tsai, Y.F.; Tseng, L.M.; King, K.L.; Chen, W.S.; Chiu, J.H.; Shyr, Y.M. Timosaponin aiii suppresses hepatocyte growth factor-induced invasive activity through sustained erk activation in breast cancer mda-mb-231 cells. Evid. Based Complement. Alternat. Med. 2013, 2013, 421051. [CrossRef] [PubMed]

80. Gao, F.; Deng, G.; Liu, W.; Zhou, K.; Li, M. Resveratrol suppresses human hepatocellular carcinoma via targeting hgf-c-met signaling pathway. Oncol. Rep. 2017, 37, 1203-1211. [CrossRef] [PubMed]

81. Amitani, M.; Amitani, H.; Sloan, R.A.; Suzuki, H.; Sameshima, N.; Asakawa, A.; Nerome, Y.; Owaki, T.; Inui, A.; Hoshino, E. The translational aspect of complementary and alternative medicine for cancer with particular emphasis on kampo. Front. Pharmacol. 2015, 6, 150. [CrossRef] [PubMed]

82. Wu, J.R.; Hu, C.T.; You, R.I.; Ma, P.L.; Pan, S.M.; Lee, M.C.; Wu, W.S. Preclinical trials for prevention of tumor progression of hepatocellular carcinoma by lz-8 targeting c-met dependent and independent pathways. PLoS ONE 2015, 10, e0114495. [CrossRef] [PubMed]

(C) 2017 by the authors. Licensee MDPI, Basel, Switzerland. This article is an open access article distributed under the terms and conditions of the Creative Commons Attribution (CC BY) license (http://creativecommons.org/licenses/by/4.0/). 